\title{
The Tendency of Using Nonstandard Indonesian in Learning Activity
}

\author{
Masda Surti Simatupang ${ }^{1}$, Ramot Peter $^{2}$, Erni Murniarti ${ }^{3}$, Hendrikus Male $^{4}$ \\ \{surtisimatupang@uki.ac.id ${ }^{1}$, ramot.peter@binus.ac.id², erni.murniarti@uki.ac.id ${ }^{3}$ \} \\ ${ }^{1}$ Faculty of Letters and Languages, Universitas Kristen Indonesia, Jakarta, \\ ${ }^{2}$ Character Building Development Center, Information Systems Department, School of Information \\ Systems, Bina Nusantara University Jakarta, \\ ${ }^{3}$ Graduate Program of Education Administration, Universitas Kristen Indonesia, Jakarta
}

\begin{abstract}
Based on Article 36 of the Indonesian 1945 Constitution, it is stated that the state language is Indonesian. In its position as the state language, Indonesian serves as the language of instruction in education. There is a tendency that Indonesian language use in formal situations is not following the rules of good and correct Indonesian. This study highlights how standard Indonesian use in situations where formal Indonesian is needed in the learning process. The research subjects were 117 UKI students who were given questionnaires using Google Form regarding the Indonesian language on campus. The results showed that the use of nonstandard Indonesian often appeared in learning. After analyzing the research results, it was found that: 1) students were able to distinguish between the standard and nonstandard Indonesian word choices; 2) not accustomed to speaking standard Indonesian, so students tend to mix standard and nonstandard Indonesian; 3 ) The absence of strict regulations and sanctions in terms of the use of standard Indonesian causes students to be less concern about practicing Indonesian as the state language.
\end{abstract}

Keywords: Constitution; learning; standard Indonesian

\section{Introduction}

Historically, on October 28, 1928, the Youth Pledge was made, which gave birth to a statement that the contents were filled with blood and one nation, namely Indonesia, and upholding the language of unity, Indonesian language. Therefore, Indonesian is used as the state language and as the language of unity. It is regulated in article 36 of the 1945 Constitution, which asserts that the state language is Indonesian. Then, in Law 24 of 2009 concerning the flag, language, and state symbol, and the national anthem, there are articles regarding the language of the state, in chapter III starting from Article 25 to Article 45.

Article 25 verse 3 states Indonesian is the official language of the state, functions as the official language of the state, as a means of instruction to education, national-level communication, national cultural development, trade transactions and documentation, as well as a means of developing and utilizing science, technology, art, and the language of the mass media. In Article 29, paragraph 1, the Indonesian language must be used as a means of instruction in national education [1]. With this explanation, it is apparent that Indonesian must be used in education, from early childhood education to tertiary institutions as the state language. Learning in classrooms, students must use Indonesian. 
The variety of Indonesian can be divided into two, the standard and nonstandard or colloquium Indonesian. Nonstandard Indonesian is used in relaxed conversations, for example, in the family and friendship domain. Nonstandard Indonesia, which can be called slang, is an oral variety of spoken Indonesian uttered mainly by teenagers. It is a mixed Indonesian, vernacular, and teenage-language-made that only teenagers understand in one area or territory. The young generation tends to use slang language instead of a formal one. It can shift the standard to slang language that caused teenagers to prefer to use slang rather than the standard one [2]. The slang words become popular and develop from their peers and neighbourhood.

It becomes trendier since the emergence of social media [3], where young people interact with one another using slang so that the adults will not understand the meaning. Everyday use of Indonesian occupies almost all fields because it is a language that is comfortable to use. It causes a mixture of standard Indonesian and nonstandard Indonesian in a place where regular Indonesian should be used. In addition, there is also the mixing of Indonesian with English or other foreign languages to show that the user can speak a foreign language as a source of pride.

Standard Indonesian is used in the realm of education, work/office, and religious environments. It is a variety that is standardized and recognized by most community members as the official language and a frame of reference for language norms in its use [4]. This standard variety, which is also called high language, is used for various formal situations. It is applied, for example, in the state and government administration, drafting laws, trials in court, meetings in the House of Representative (DPR) and People's Consultative Assembly (MPR), broadcasting news through electronic and print media, speeches in public, and the administration of education [5].

Standard Indonesian is the language used by focusing on the rules' provisions, choosing the correct vocabulary, and sentences fitted to the regulation. In the spoken form, the uttered standard Indonesian relates to the correctness of the rules, including grammar, pronunciation, intonation, precise and one-way expressions [6]. For example, in their teaching, lecturers using PowerPoints will explain learning materials using formal Indonesian, offline and online.

Language is effective if a speaker or a writer knows what kinds of varieties are used concerning certain situations or conditions. For example, a student will speak formally and politely when he/she meets his/her lecturers on campus. When meeting with friends in the canteen, he/she will spontaneously switch to non-formal or regional dialects. The language will be shifted to a vernacular language when he/she meets another student from the same hometown. Likewise, with the type of writing, a student will write an essay assignment using standard Indonesian. He/she will switch his/her notes to the local Indonesian variety or even slang when chatting with friends via WhatsApp.

Standard language in education will be used in scientific writing (essays, articles, papers, activity reports, and research reports). However, several studies stated that students did not fully use standard Indonesian in written assignments in classes. An example was the writing of speech texts by high school students who mixed Indonesian and foreign languages [7]. In addition, the writing of student scientific papers was written not following the rules of the Indonesian language, including errors in capital and italics, the form of absorption of foreign words, the use of terms that were not in the right situation, cutting remarks, and redundant comments [8]. Other mistakes were using words that did not correspond to the words in the Big Indonesian Dictionary (KBBI). These errors were found in the student Instagram captions [9].

In the oral mode, students are required to use standard Indonesian at the time of presentation, either for individual or group presentations in class or when attending seminars, 
workshops, or conferences. Students have not thoroughly carried out the use of standard Indonesian following the rules of the language on campus and Indonesian society in general. It can be caused by several factors, i.e., accustomed to using slang among adolescents or university students [10] [11], lack of pride in using Indonesian [12], inserting foreign languages in Indonesian so that the presentations will be considered excellent [13], or other reasons.

None of that previous research discussed the tendency of using nonstandard Indonesian in students' oral presentation in class. Hence it is crucial to consider using standard Indonesian in-class presentation. This research should establish awareness for university students to use standard Indonesian in education situations consistently. Standard Indonesian, which is the focus of this research, is the accepted spoken language used by students in the teaching and learning process, especially when presenting a topic with or without slides. This research was conducted to determine how Indonesian is used orally in teaching and learning processes. Second, it describes the factors for university students to mix standard and nonstandard Indonesian in their utterances.

\section{Research Methods}

Theoretically, this study uses sociolinguistics (language in society) and pragmatics (language used based on context). It was the phenomenon because we speak distinctively in different social contexts [14]. This research uses qualitative methods to explain the further use of Indonesian varieties in a particular society, mainly in an education environment. The data in this study primarily gathered from filling out questionnaires by 117 Indonesian Christian University students from six faculties consisting of $67 \%$ women and $33 \%$ men. The research data was taken from 14 questions regarding the mixing of standard and nonstandard varieties and the existing regulations on the use of standard Indonesian. Besides, the data was taken from observing the class when students orally presented their class presentation topics. The data were then analysed using percentages and explained using standard and nonstandard Indonesian language among students.

\section{Results and Discussion}

The results of this study were divided into two parts, first, regarding the mixing of standard and nonstandard Indonesian varieties, and second, regarding the regulation of the use of standard Indonesian. From the fourteen questions delivered to students, five questions asked students' use of standard and nonstandard Indonesian, four regarding the mixing varieties, and five about the rules of using standard Indonesia. The first question was about the use of standard Indonesian in the learning process. In this study, 53\% of students thought that they used standard Indonesian in the learning process, 39\% said no, and the rest did not know. It indicated that students understood that standard Indonesian must be employed in the learning process, and they applied it well. However, based on observations, there were still many students who mixed it with nonstandard language expressions.

The second question was about the language used in interacting with friends. $68 \%$ of students stated that they interacted with friends on campus using informal Indonesian, $27 \%$ indicated that they used standard language, and the rest asserted that they did not know. It was 
in line with the sociolinguistic theory, which stated that in the domain of friends and family, people used informal language, regional language, or slang [14]. In the interaction between participants who had close relationships, a natural or local language was applied. Thus, it was natural to use colloquial language in the realm of family and friends. In this domain, there was a sense of closeness for each member, and they would feel free to express themselves in the language of comfort.

The third question was about interactions with lecturers. 90\% of students agree that standard Indonesian was used when interacting with lecturers in or out of campus. There was a formal impression when meeting with a lecturer, even if the situation was casual. It showed that students knew when and with whom they spoke using standard Indonesian. The application of the use of standard Indonesian by students to lecturers was beyond doubt. Likewise, when communicating with other educators, for example, the Head of the Study Program or the Dean, students constantly used standard Indonesian, except for students majoring in English, who were required to speak English with the lecturers. In the formal situation with a condition of participants behave officially with no intimate relation, the participants react formally and utter standard language to each other [15].

The fourth question was about using nonstandard Indonesian in the classroom, whether students were influenced by their friends who did not use standard Indonesian. $45 \%$ said they disagreed, $42 \%$ agreed, and the rest didn't know. The number of approved and counter statements for this section did not show a significant difference. It meant that students could be influenced or not to use the nonstandard Indonesian language. For this reason, the role of lecturers was essential to keep reminding the use of standard Indonesian during the lecture process. If lecturers let students not use formal Indonesian, they thought it was not too important to use formal Indonesian in class.

The fifth question asked whether students can distinguish between standard and nonstandard Indonesian. 78\% stated that they understood and knew the difference. Only 16\% said they did not know, and $6 \%$ were confused. It indicated that students learned the variety of standard Indonesian and acknowledged when and to whom they used it. Nevertheless, errors in the use of formal language were still found. For example, during students' presentations, they still used a mixture of standard and nonstandard languages for oral modes. For written types, in scientific writing made by students, there were errors in using standard language at the level of words, phrases, sentences, and paragraphs [16].

In the sixth question concerning conversations between students during learning activities, $50 \%$ of students used nonstandard Indonesian, while $42 \%$ used standard Indonesian. It denoted that more students used standard Indonesian in the learning activities. What needs to be considered was that each lecturer should remind students to use standard Indonesian when studying in a class situation, even if the conversation was between students. In the domain of friendship, it belongs to the category of using nonstandard language use. However, in the education context, nonstandard language should be changed to a standard one.

The seventh question was about the use of the Indonesian language when communicating with lecturers. $75 \%$ agreed that students used standard language when speaking with their lecturers. It had been a habit for students to use standard language when a lecturer existed in their group. It indicated that students would politely behave themselves when meeting their lecturer.

Concerning class materials delivered by lecturers, $60 \%$ of students admitted that the language used in the PowerPoint created by lecturers applied standard Indonesian. It revealed that lecturers had used standard Indonesian. However, there were $27 \%$ of students opposed the statement. Therefore, even if it was a small percentage, some reports of the language used in 
the lecturer's PowerPoint were not standard. It should be an introspection for lecturers to use solely standard Indonesia in the slide presentation.

Regarding students' oral presentation in class, $67 \%$ of the students stated they mixed standard and nonstandard Indonesia. After reading the slides using standard Indonesian statements, students sometimes uttered nonstandard language since they felt comfortable speaking informal Indonesian and sometimes mixed with their regional dialects. From class observation, it was discovered that using formal Indonesian while presenting their topic caused them to be exhausted. Their total concentration to choose appropriate diction, correct grammar, proper intonation, and effective sentences to speak properly demanded more energy, which caused them tired.

In the tenth question, students were required to answer about the Indonesian language spoken by their lecturers. $47 \%$ of them thought that their lecturers had already applied standard Indonesian. On the contrary, $44 \%$ of students said that their lecturers mixed the variety. It was similar to the findings of students' oral presentation of using mixed language. In other words, the lecturers and the students mixed their language in their spoken presentation.

Question concerning warning of using the Indonesian language, 50\% students said that the lecturer warned them when using nonstandard Indonesian in class; while $40 \%$ said the contrary. Law 24 of 2009 regarding the flag, language, and state symbol, and the national anthem stated that the Indonesian language was a means of instruction to education. As a consequence, it is a must to use the Indonesian language in teaching and learning interaction. Furthermore, a lecturer or a teacher should speak with standard Indonesian and has a right to reprimand his/her students for using Indonesian appropriately. It would be worthy for students to be reminded of using standard Indonesian. A lecturer as a role model in class will significantly influence class to motivate them to use standard Indonesian [18].

In the twelfth question concerning the penalty of using nonstandard Indonesian, 55\% of students said that the lecturer did not give sanction or penalty for students who speak nonstandard Indonesian, 25\% said yes, and 20\% said they did not know. Regulation using standard Indonesian was clearly stated in the 1945 Constitution in Article 36 and further in Law 24 of 2009. However, there were no cases of breaking the rules that caused people were set in jail. Not using standard Indonesian in education will never be given punishment. Even educators responsible for employing formality in the educational situation do not utilize the strict rules of applying standard Indonesian on campus. It might cause students did not focus on using standard Indonesian, or even though they did, they might use the language properly when presenting one topic, asking and answering questions from lecturers. For the rest of the class activity, they mostly used the local language.

The lecturer's role in the practice of teaching and learning is very significant since he/she should manage his/her class thoroughly. As a manager in his/her class, the lecturer designs lectures from the first to the last meeting. In addition to preparing Semester Lesson Plans, namely topics for one semester, a lecturer also arranges the methods, assignments at the end of each learning outcome, quizzes designed in each lesson, and questions at the end of learning outcomes. Another important thing for a lecturer to consider is that he/she should formulate the rules for one semester for students to follow to achieve the learning objectives. This code of conduct should state how the Indonesian language is used during lectures. It must be determined that standard Indonesian is required as a means of instruction, both in the interaction between lecturers and students or students and students.

From the results of the thirteenth questionnaire, $48 \%$ of students stated that lecturers set regulations to use standard Indonesian during class learning. It showed that the lecturers were 
serious about the use of formal Indonesian in education. Nonetheless, $38 \%$ stated that lecturers did not set regulations on the use of standard Indonesian. Students used Indonesian in class because of their awareness of applying the standard language, even though it was mixed with the local one. If the lecturer applied the stipulation of the use of standard Indonesian in the class seriously, students would follow his/her rules. The role of the lecturer needs to be improved to encourage excellent and correct use of Indonesian in the campus environment.

The last question was about the regulation from the university. Half of the students stated that the university applied the rules of using standard Indonesian, while $28 \%$ said not and $22 \%$ did not know. If a university applied standard Indonesian regulations to the academic rules or student academic guidelines, this would become a reference for academicians to use standard Indonesian. Based on these rules, lecturers can emphasize the use of standard Indonesian in class with more discipline in any subject, except for those requiring the use of foreign languages suited to their majors. It will be a derivative of regulations taken from Law 24 of 2009 concerning the Indonesian language in education.

It also showed the seriousness of the university as an educational institution to oblige the use of standard Indonesian. The effect would be students' seriousness of using formal Indonesian in every subject, especially when taking an Indonesian language course. Thus, it is expected that students will be required and accustomed to using standard Indonesian in every lesson. So, the use of standard Indonesian can always be applied to any formal situation. Furthermore, even though students as the young generation tend to use slang in daily conversations, they can easily change the code to standard language in an official atmosphere. Whether in written or spoken form, formal language will minimize the misunderstanding often found in slang.

In other words, it was necessary for an affirmation from either the university or the lecturers always to apply the use of standard Indonesian in every learning and teaching process. It will be a role model for students to follow their lecturer's directions. Hence, it is expected that standard language can be maximized and non-standardized can be minimalized even though it is not simple to use standard language among students accustomed to slang or vernacular languages. National language discipline is required by complying with all rules or regulations to use the Indonesian language [19]. Thus, there will be pride in using standard Indonesian because one of the characteristics of educated people is using standard language in official situations. Educational and socioeconomic background affects the variety of a person's conversation - the higher a person's socioeconomic class, the better the use of standard language [17].

Awareness of using the Indonesian language increases people's understanding of the importance of the role of the standard language. For example, standard Indonesian is a suitable instrument to realize the value of legal certainty in forming laws and regulations [20]. Another example is Indonesian use on span cloth, nameplate, and other general means of communication that do not follow Indonesian rules [21]. Therefore, it is necessary to regulate or manage the Indonesian language on ranges and name boards. There should be public awareness of the importance of using the correct Indonesian language.

\section{Conclusion}

Students know where and when to use standard Indonesian, but nonstandard Indonesian has a significant impact on everyday use, either in education situations or not. Lecturers 
realized that they should use standard Indonesian in their PowerPoint materials or when explaining the lesson as a role model of using standard Indonesian in an oral presentation. However, they should always remind students to utter good Indonesian regularly to show that they are educated. It can increase their awareness to use standard Indonesia in the formal situation.

The factors for students not using standard Indonesian: first, no reward or penalty concerning the use or not using of standard Indonesian as a state language. It affected students' seriousness in delivering the language. To increase students' awareness, they need to be motivated to use the language properly by retelling them the prominent status of the Indonesian language as our identity as a nation. Second, no strict rules for using formal Indonesian in educational contexts. If a university or lecturers can provide one, it shows the seriousness of the university as an educational institution to oblige the use of standard Indonesian. The effect would be students' seriousness of using formal Indonesian in every subject and an official meeting.

\section{Suggestion}

It is suggested for a university to consider having a written regulation of using standard Indonesian in every learning situation. Besides, there should also be available some competitions or training of using standard Indonesian. For example, by providing severe training of using standard language to one particular group, like the freshman. It could result that student are motivated to use formal language because, principally, they know and can use Indonesian grammar rules correctly and adequately.

\section{References}

[1] UU Nomor 24 tahun 2009 tentang Bendera, Bahasa, dan Lambang Negara, serta Lagu Kebangsaan. 2004.

[2] R. P. Suminar, "Pengaruh Bahasa Gaul terhadap Penggunaan Bahasa Indonesia Mahasiswa Unswagati," J. Log., vol. 18, no. 3, pp. 114-119, 2016, [Online]. Available: www.jurnal.unswagati.ac.id.

[3] D. Franesti, "Eksistensi Penggunaan Bahasa Indonesia yang Baku di Kalangan Remaja," in FKIP eProceeding, 2021, pp. 39-50.

[4] E. Z. Arifin and S. A. Tasai, Cermat Berbahasa Indonesia untuk Perguruan Tinggi. Akademika Pressindo, 1995.

[5] H. Lapoliwa, "Lafal Bahasa Indonesia Baku," 1998.

[6] Barowi and S. F. F. ABA, "Pentingnya Pembelajaran Bahasa Indonesia di Perguruan Tinggi," vol. 03, no. 01, pp. 59-74, 2015.

[7] T. Setiawati, J. Y. Prameswari, and Y. Agustin, "Penggunaan Bahasa Tidak Baku pada Teks Ceramah Siswa Kelas XI SMK Kharismawita dan Implikasinya terhadap Pembelajaran Bahasa Indonesia,” Alegori J. Mhs. Pendidik. Bhs. Indones., vol. 1, no. 1, 2021.

[8] J. Jamilah, "Penggunaan Bahasa Baku dalam Karya Ilmiah Mahasiswa," J. Tarb. J. Ilm. Kependidikan, vol. 6, no. 2, pp. 41-51, 2017, doi: 10.18592/tarbiyah.v6i2.1603.

[9] Y. N. Yastini, A. R. Nurdian, and Wikanengsih, "Kemampuan Penggunaan Bahasa Baku Mahasiswa Program Studi Bahasa Indonesia IKIP Siliwangi di Media Sosial Instagram,” Parol. J. Pendidik. Bhs. dan Sastra Indones., vol. 1, no. 4, pp. 475-480, 2018.

[10] A. P. Rahayu, "Menumbuhkan Bahasa Indonesia yang Baik dan Benar dalam Pendidikan dan Pengajaran," J. Paradig., vol. 2, no. 1, pp. 1-15, 2015, doi: 10.33096/tamaddun.v16i2.55.

[11] N. Nurhasanah, "Pengaruh Bahasa Gaul terhadap Bahasa Indonesia," Forum Ilm., vol. 11, no. 1, pp. 15-21, 2014, doi: 10.31219/osf.io/w94xy. 
[12] U. Mansyur, "Sikap Bahasa dan Pembelajaran Bahasa Indonesia di Perguruan Tinggi," 2018, doi: 10.31227/osf.io/te3df.

[13] N. P. Putri, "Eksistensi Bahasa Indonesia pada Generasi Millennial," Widyabastra, vol. 05, no. 1, pp. 45-49, 2017, doi: 10.1515/9783112372760-010.

[14] J. Holmes, An Introduction to Sociolinguistics, Fourth. New York: Routledge, 2013.

[15] M. Fakhrudin, "Penerapan Kaidah Berbahasa Dalam Percakapan Berbahasa Indonesia," J. Lang. Learn. Res., vol. 1, no. 1, pp. 41-57, 2017, doi: 10.22236/JOLLAR.

[16] R. A. Setiorini, "Analisis Penggunaan Tata Bahasa Indonesia dalam Penulisan Karya Tulis Ilmiah : Studi Kasus Artikel Ilmiah,” Visi Pustaka, Perpust. Nas. R.I., vol. 12, no. 1, pp. 16-24, 2010.

[17] E. Rukiah, "Ragam Bahasa Remaja Puteri Dalam Percakapan Informal di Kampus UPI Tasikmalaya," Saung Guru, vol. 1, no. 2, pp. 79-83, 2010.

[18] Noermanzah, "Peran Dosen dan Sastra Indonesia dalam Mempertahankan Bahasa Indonesia Sebagai Alat Pemersatu Negara Kesatuan Republik Indonesia pada Era Globalisasi,” in Prosiding Seminar Nasional Bulan Bahasa UNIB 2015, 2015, pp. 274-284, doi: 10.1515/9783112372760013.

[19] S. Murti, "Eksistensi Penggunaan Bahasa Indonesia di Era Globalisasi," in Prosiding Seminar Nasional Bulan Bahasa UNIB 2015, 2015, vol. 1, no. 2, pp. 177-184, [Online]. Available: http://repository.unib.ac.id/11123/1/18-Sri Murti.pdf.

[20] R. Riana and M. Junaidi, "Konstitusionalisasi Pembentukan Peraturan Perundang-undangan Melaui Penggunaan Bahasa Indonesia Baku,” J. Legis. Indones., vol. 15, no. 4, pp. 275-283, 2018.

[21] Martina, Penggunaan Bahasa Indonesia pada Kain Rentang dan Papan Nama di Kota Pontianak, 1st ed. Pontianak: Balai Bahasa Propinsi Kalimantan Barat, 2015. 